\title{
Evolution of white and megatooth sharks, and evidence for early predation on seals, sirenians, and whales
}

\author{
Cajus G. Diedrich
}

Paleologic, Petra Bezruce 96, Zdice, Czech Republic; cdiedri@gmx.net, www.paleologic.eu

Received 6 April 2013; revised 6 May 2013; accepted 13 May 2013

Copyright (C) 2013 Cajus G. Diedrich. This is an open access article distributed under the Creative Commons Attribution License, which permits unrestricted use, distribution, and reproduction in any medium, provided the original work is properly cited.

\begin{abstract}
The early white shark Carcharodon Smith, 1838 with the fossil Carcharodon auriculatus (Blainville, 1818) and the extinct megatooth shark Otodus Agassiz, 1843 with species Otodus sokolovi (Jaeckel, 1895) were both present in the European proto North Sea Basin about 47.8 - 41.3 m.y. ago (Lutetian, early Middle Eocene), as well as in the Tethys realm around the Afican-Eurasian shallow marine habitats. Both top predators developed to be polyphyletic, with possible two different lamnid shark ancestors within the Early Paleocene to Early Eocene timespan with Carcharodon (white shark line-age) and Otodus (megatooth shark lineage). Their sawblade teeth developed during the early Paleogene as the result of adaptation to feeding on various marine new rising mammals, coinciding with three main waves of evolutionary emergence of seals, sirenians, and whales in parallel with the evolution of these large predatory sharks. Megatooth sharks specialized in hunting whales and sirenians only on the coastal shelves of warm oceans and disappeared globally in the Pleistocene due to climate change and ocean cooling. The cold-water adapted early white sharks have survived until the present day with body temperate change adaptation in warm to temperate oceans and are proposed to have specialized on coastal seal hunting already 50 m.y. ago.
\end{abstract}

Keywords: Megatooth/White Shark Evolution; Palaeobiogeography; Marine Mammal Coevolution; Palaeoecology

\section{INTRODUCTION}

Large, serrated, fossil shark teeth from Tertiary sedi- ments were generally first attributed to "white shark Carcharodon carcharias (Linné, 1758) ancestors". Controversy has subsequently arisen whether they should be ascribed to the megatooth shark ("Carcharocles"- -herein Otodus), or to the white shark (Carcharodon) lineage [1]. This controversy is partly a result of non-systematic excavation of single serrated similar looking teeth from many localities around the world, and from horizons of different ages. DNA studies have at least resolved the general position of the extant form of Carcharodon carcharias, placing it between the Isurus and Lamna genera [2,3], without taking into account a revision and including of extinct fossil species such as Otodus. The monophyletic evolutionary models that consider this genus Otodus to be a direct ancestor of the megatooth sharks [4] have recently received strong support, which can be supported furthermore with new Eocene tooth finds from Germany (Figure 1).

Complete megatooth and white shark skeletons, and even their teeth, are scarce in the Paleocene and Eocene around the world. A single incomplete set of teeth from Carcharodon auriculatus (Blainville, 1818), which is an Eocene relative of the white shark, was illustrated by Storms in 1901 [5]. Rare articulated skulls, tooth sets, or vertebral columns from megatooth sharks have been reported from the Oligocene species Otodus angustidens (Agassiz, 1843) [6,7], as well as from the Miocene species "Otodus turgidus (Agassiz, 1843)" whose latter validity is disputed herein [5] and, more commonly, from the Miocene to Pliocene species Otodus megalodon (Agassiz, 1843) [8,9].

The Middle Eocene shark tooth and coprolite-rich [10, 11] sites in north-western Germany, which also contain few marine mammals, recently became important following the discovery of the world's oldest seal remains with a femur and humerus fragment [12], and newest sirenians remains with a rib and vertebra fragments [13]. Only $1 \%$ are such mammals, and $99 \%$ of the vertebrates 


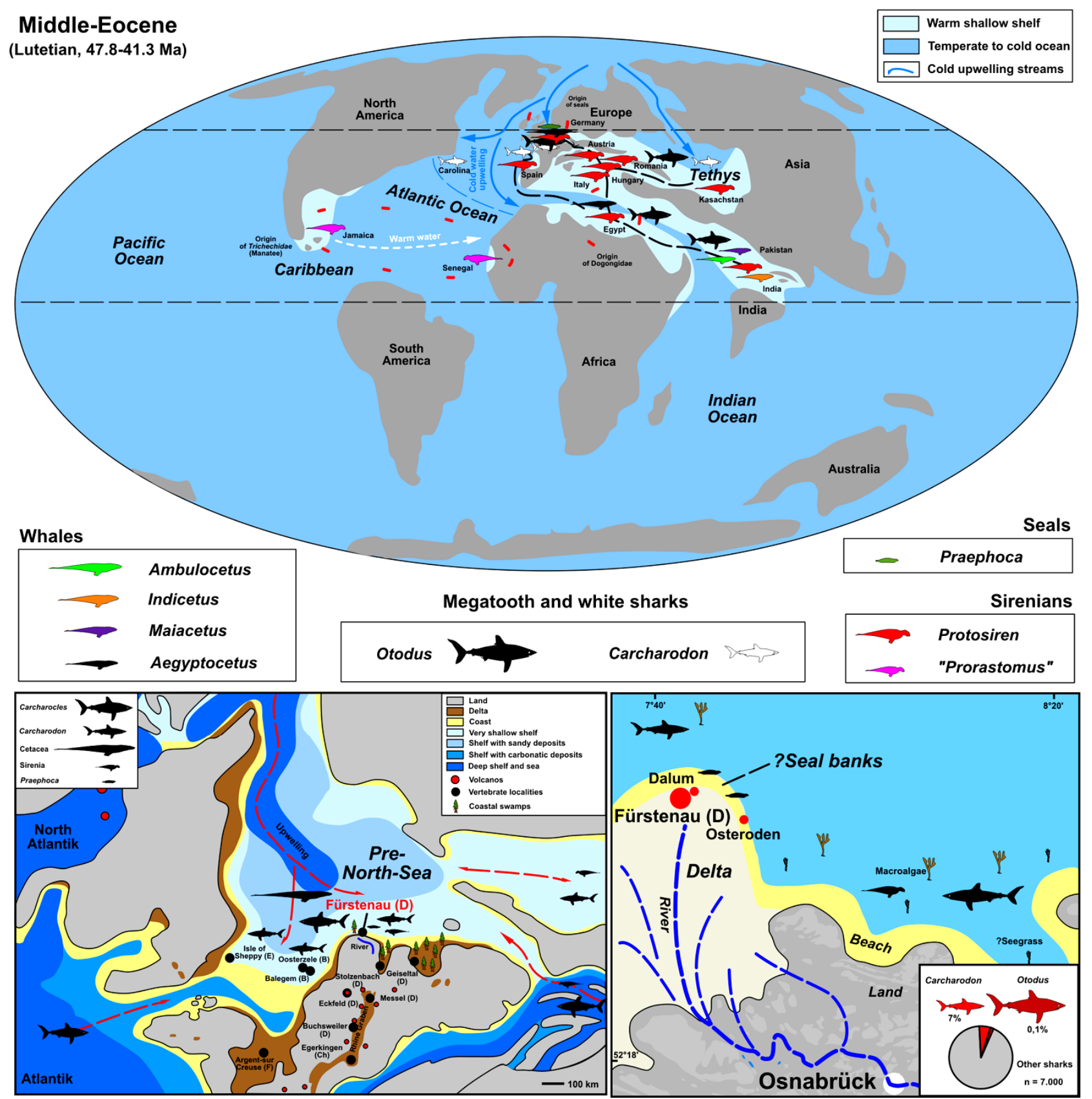

Figure 1. Global distribution of Middle Eocene (Lutetian) megatooth sharks and white sharks, and their migratory marine mammal prey. Seals were hunted along the beaches of the southern proto North Sea Basin, especially north of Osnabrück (palaeogeography of the Midlde Eocene and important fossil sites of Europe compiled from [10,12,13]).

are isolated shark (mostly abundant teeth) and fish remains $[10,11]$. Over the past 25 years large quantities of teeth were sieved from the same layer at two smaller localities (Dalum and Osteroden) near Fürstenau (northern Germany, Figure 1) by two private collectors and more recent the author in a large systematic excavation campaign in 2011 [10]. Both, megatooth sharks and the ancestors of the white sharks have been unearthed from gravels with about 2000 specimens. This large amount of finds, which are described herein with focus in the context of predator/prey relationships of marine mammals-giant sharks, are from a period that is close to the origin of both of these shark genera in the Early to Middle Eocene Lutetian [14].

\section{MATERIAL AND METHODS}

During 2011 Europe's largest shark tooth excavations were completed by the author at two shallow marine fos- 
sil sites (Dalum and Osteroden) in north-western Germany, together with geological and palaeontological surveys, as an interdisciplinary research project for the Visitor Center at the UNESCO Terra.Vita Geopark/that built up recently the SharkCenterBippen; German $=\mathrm{Ha}-$ izentrum Bippen $=\mathrm{SCB}$ ) [10]. A large total of 180 cubic meters of conglomeratic material was removed from the Dalum forest site for sieving, of which little over $0.1 \%$ $(250 \times 10$ litre buckets) has been sieved to date. A further 10 cubic meters were removed from the Osteroden sand pit site, but most of this remains un-sieved. The gravel from Dalum was wet-sieved into two size fractions $(+4$ $\mathrm{mm}$ and $4-1 \mathrm{~mm}$ ) and examined for vertebrate, invertebrate, and other fossil remains. At this campaign about 14.400 fossils (95\% are shark teeth) have been found and analysed preliminary only on this public collection of the Geopark Terra.Vita, including some material of white and megatooth teeth [10].

The large private collection owned by H. Felker (included in future in the SCB), which was accumulated over 25 years from these sites with exact stratigraphic context and acribic sorting of all grain sizes (fractiony down to $1 \mathrm{~mm}$ ) ranging over all fossil groups: foraminivers to megatooth shark teeth, and terrestrial mammal teeth), was additionally included in this study. This large amount of material is not to obtain in a short-term excavation campaign, and both combined allowed finally statistical analyses of both collections [10]. Whereas the excavation allows clear fossil amounts, the private collection allows presenting the biodiversity (rare fossils) and analyses of selected species with better amounts. This collection contains approximately 250,000 shark teeth, about 12,000 fish otoliths [15], many different kinds of macro invertebrate, and vertebrate fossils that include a few terrestrial mammal teeth and marine mammal bone fragments $[10,12,13]$. From this collection, together with the newly excavated material, about 2000 serrated teeth from Carcharodon and Otodus were separated for this study. Those teeth often are only tooth crowns or incomplete teeth without roots which can not be determined even to the genus. However, this material represents the largest number of serrated teeth ever analysed globally from a single layer (Eocene condensation bed). This German Middle Eocene material was compared with other large serrated teeth from the German Oligocene sites (Doberg, Astrup, Eckelshein, Alzey, and Espenhain) [13] in order to understand the early evolution of white and megatooth shark dentitions with focus on the proto North Sea Basin during the Paleogene and Neogene. Tooth material from the species discussed herein was also compared with material in a number of other collections, both public and private, or published on the internet. Finally, the marine mammal record from German Eocene sites has been extended with the discov- ery of the earliest known (fragmented) seal (herein added a new humerus fragment), sirenian [13] and possible whale material (vertebra fragments and rib/longbone fragment), which is of great relevance to discussions on the predator-prey relationships, ecology and evolution around the world.

The Oligocene material used for comparisons is housed in the Geologische Museum Ostwestfalen-Lippe, Dobergmuseum Bünde (GMOL) and the Museum Niernstein (MNIE). The Eocene material described herein is in the Shark Center, Bippen: German = Haizentrum Bippen (SCB) of the Geopark Terra.Vita, and the private collection of H. Felker in Ankum (HF). The material figured herein is housed all in the SCB.

\section{DISCUSSION}

\subsection{Origin and Evolutionary Model}

DNA and cladistic analyses [2,3] have in the past failed to provide a satisfactory model for the evolution of Carcharodon and Otodus. However, consideration of climate indicators, predator/prey relationships, coevolution of predators and prey (such as possible convergent evolutionary developments), and analyses of dental morphology, combined with access to extensive new material from the Middle Eocene of Europe, has led to the development of the new model presented herein which differs in many ways to the recently compiled models $[16,17]$, which are not repeated, because they are based on many herein used primary publications. This new and not only cladistic model is based on a polyphyletic origin for these two predatory large sharks, which already occupied different ecological niches and had different water temperature preferences by the Middle Eocene (Figure 1).

\subsection{Evolution-Monophyletic or Polyphyletic?}

DNA analyses have placed modern Carcharodon white sharks between the Isurus and Lamna lamnid sharks [3] (Figure 2), with their separation suggested to have occurred in the Early Eocene [2]. Although to date, there has been no material available to support this thesis, which can be added herein. The extinct Late Paleocene to Early Eocene Otodus genus, whose dental unserrated characteristics are more closely related to Lamna (also symphyseal teeth) than to Isurus, was included in the analyses (Figure 2). The massive rounded root bases of Otodus teeth, which is a plesiomorphic character in all lamnid teeth from the Eocene (including the lamnid Jaeckelototus) [10,16], are very similar to those of all teeth (both anterior and posterior) from the megatooth shark Otodus sokolowi, as well as those in the anterior teeth of Carcharodon orientalis and Carcharodon 


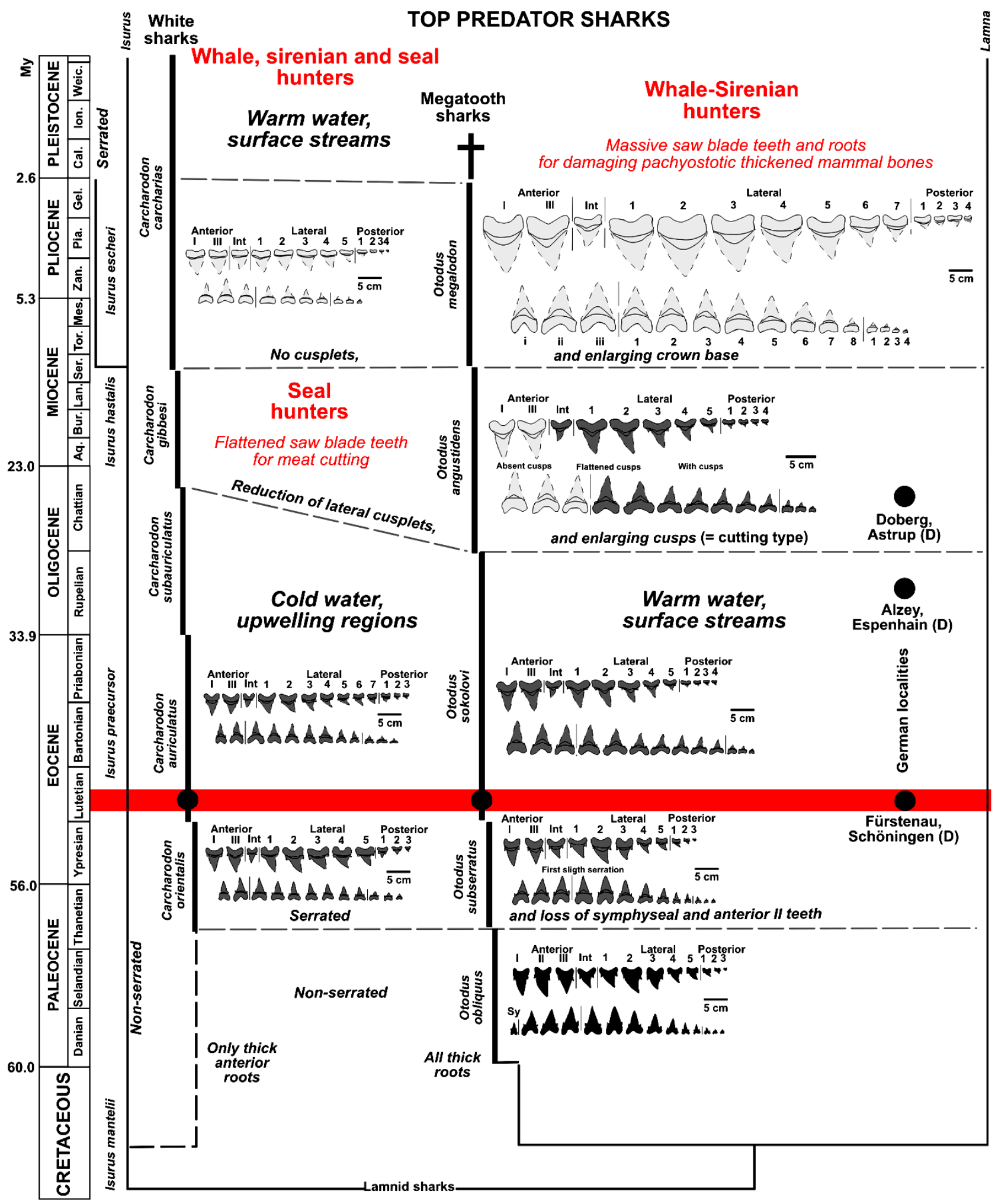

auriculatus (Figures 1 and 2). The tooth root morphology of Carcharodon is, however, more closely related to that of Isurus, whose anterior teeth have prominent but lateral teeth have flattened roots. This is the main tooth charac- ter to distinguish those genera from each other. The overlap in anterior teeth seem to have confused in the past the exact attribution to megatooth or white shark ancestors. It is suggested herein that Otodus and Car- 


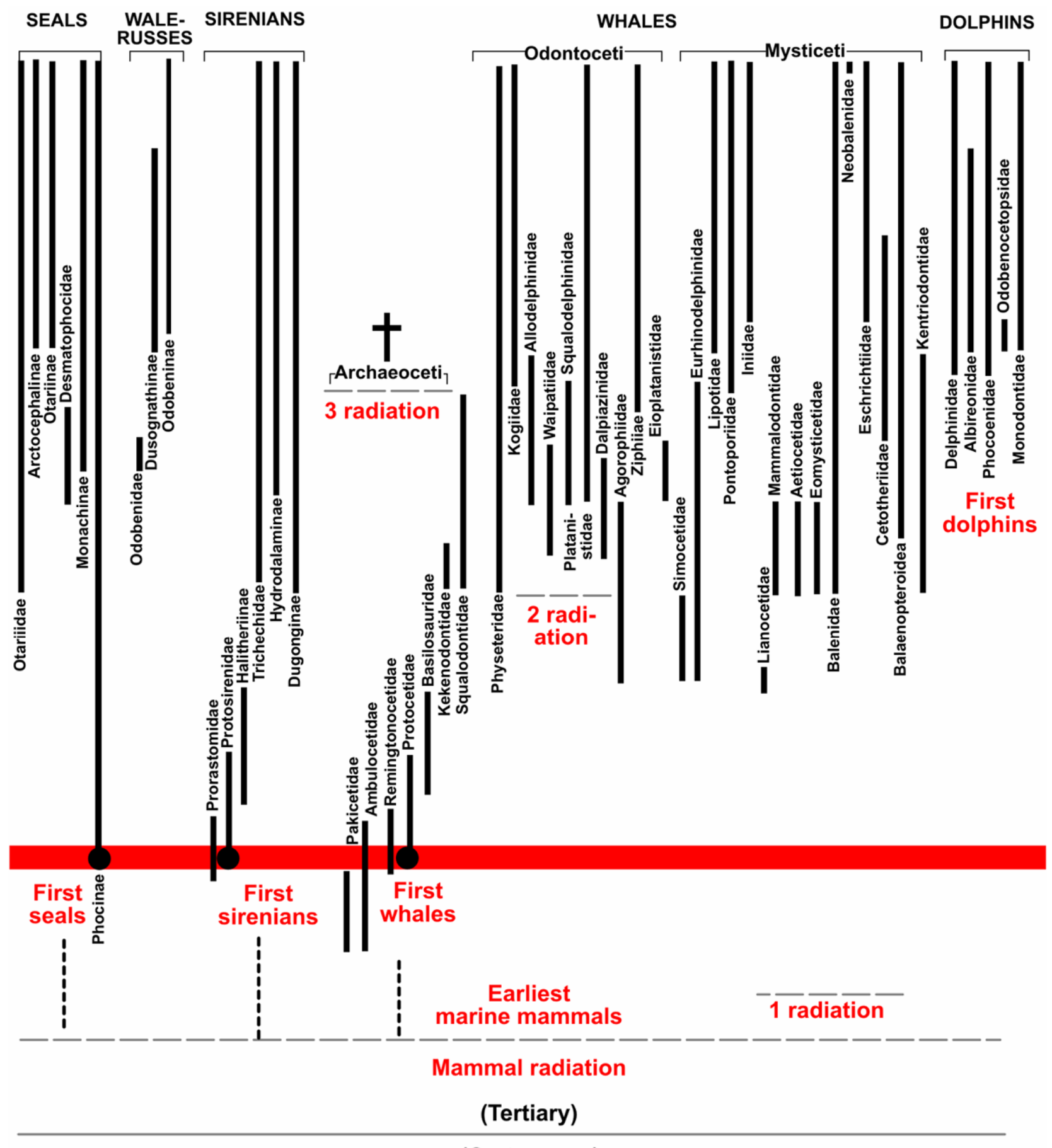

(Cretaceous)

\section{Mosasaurs, pliosaurs, marine crocodiles}

Figure 2. Evolution of the megatooth and white shark lineages, and coevolution with their largest marine mammal prey (redrawn after $[2,4,7,12,13,16,17,22,24,28,42,57,58]$ using the international chronostratigraphical chart 2012 [59] and compiled to include the new results).

charodon each had different ancestors (Figure 2), and that their tooth serration is a convergent development that may even have occurred twice in Isurus lineage (during the Paleocene in Carcharodon orientalis, and 
again during the Pliocene in Isurus escheri [14,17,18]). A similar serration happened also in other shark groups in "short-terms" such as in Squalicorax during the LowerMiddle Cenomanian [16]. Therefore, serration of shark teeth also in the herein described megatooth and white sharks must be expected to have happened also in "shortterm" as demonstrated herein in Figure 2. There were already two separate large shark lineages with well serrated teeth [2] (Figures 2-4) in the Late Paleocene and/or Early Eocene, as can be clearly obtained in fossil material from northern Germany (Figures 2-4). It appears, that both lineages were polyphyletic, with Isurus being the most probable ancestor of Carcharodon, having developed a little earlier during the Early Paleocene-first serration wave [2] (Figure 2), whereas Otodus only evolved a very few later during the Late Paleocene to Early Eocene to species with serrated teeth from unclear lineage more related to Lamna due to symphyseal teeth and dentition formula (cf. Figure 2). The possibility that both
(Carcharodon and Otodus) have only Otodus as a single monophyletic ancestor is, excluded herein by dentition formula, and tooth root characters mainly (Figure 2).

\subsection{White Shark-Carcharodon Lineage}

Carcharodon carcharias (Linnaeus, 1758) is the correct oldest reported genus and species with extant holotype species "Squalus carcharias Linnaeus, 1758". This white shark was attributed later to the genus Carcharodon Smith, 1938. Therefore, it is invalid to use for megatooth/white sharks the younger synonym of fossil tooth genus Carcharocles Jordan and Hannibal, 1923. Their type-species is the fossil white shark "Squalus auriculatus Blainville 1818", which was mentioned correctly as Carcharodon auriculatus by Agassiz, 1843. Younger synonyms used are Procarcharodon Case, 1981.

The oldest fossil white sharks date from the Middle to Late Paleocene (Thanetian), with the earliest serrated

\section{Anterior}
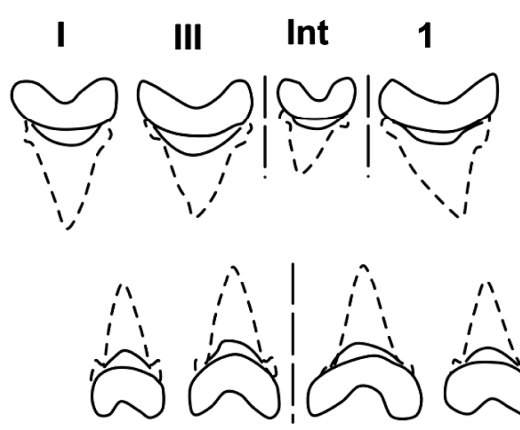

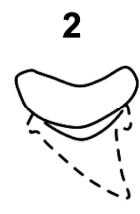

\section{Lateral}

\section{Posterior}

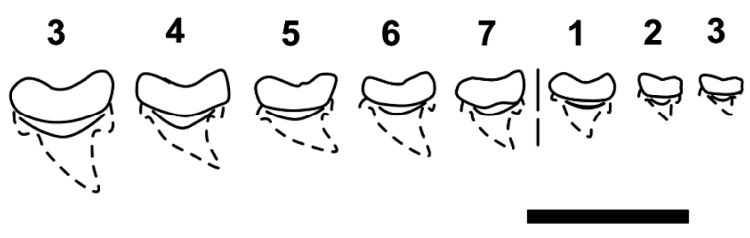

\section{$5 \mathrm{~cm}$}
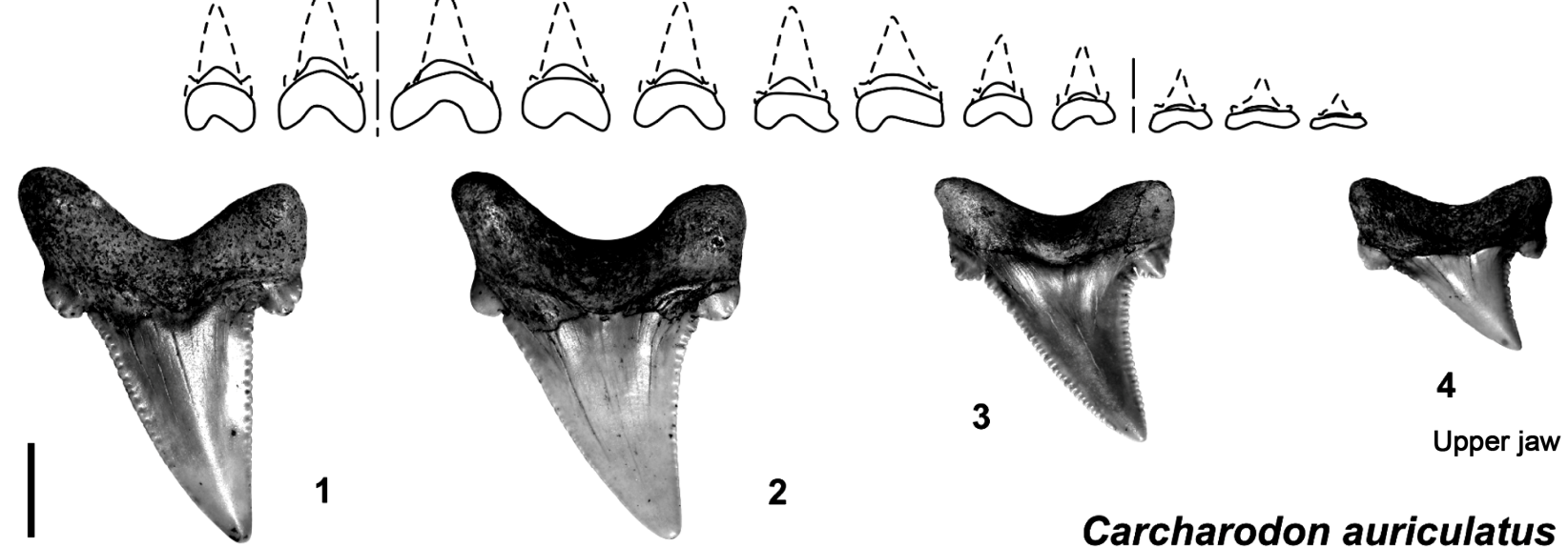

2

\section{Carcharodon auriculatus}
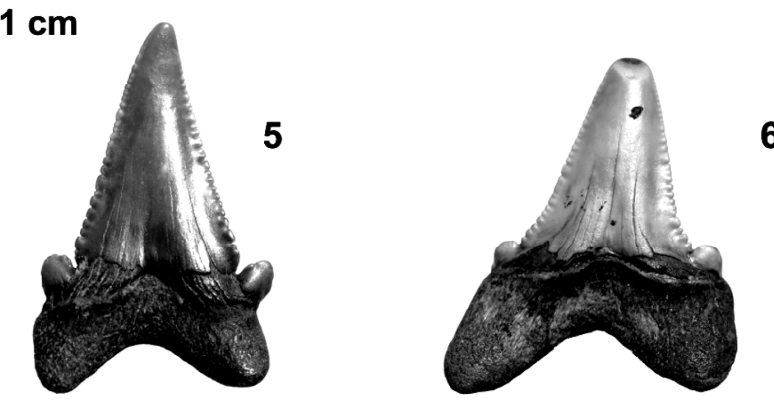

6
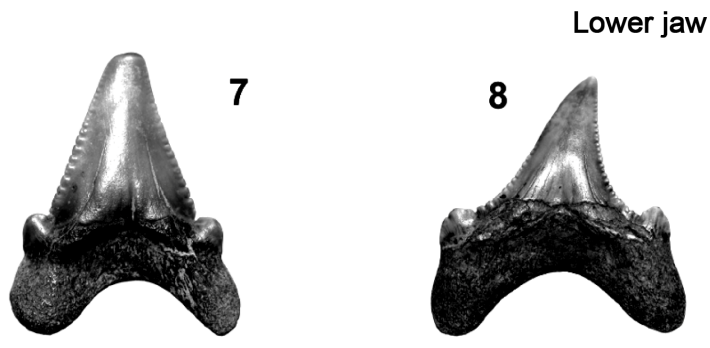

Figure 3. Parts of tooth sets from the white shark ancestor Carcharodon auriculatus ( 1 - 8 coll. SCB) from the early Middle Eocene (Lutetian) gravels of Dalum, north-western Germany, which also include reworked Late Paleocene to Early Eocene material (all in the SCB). 

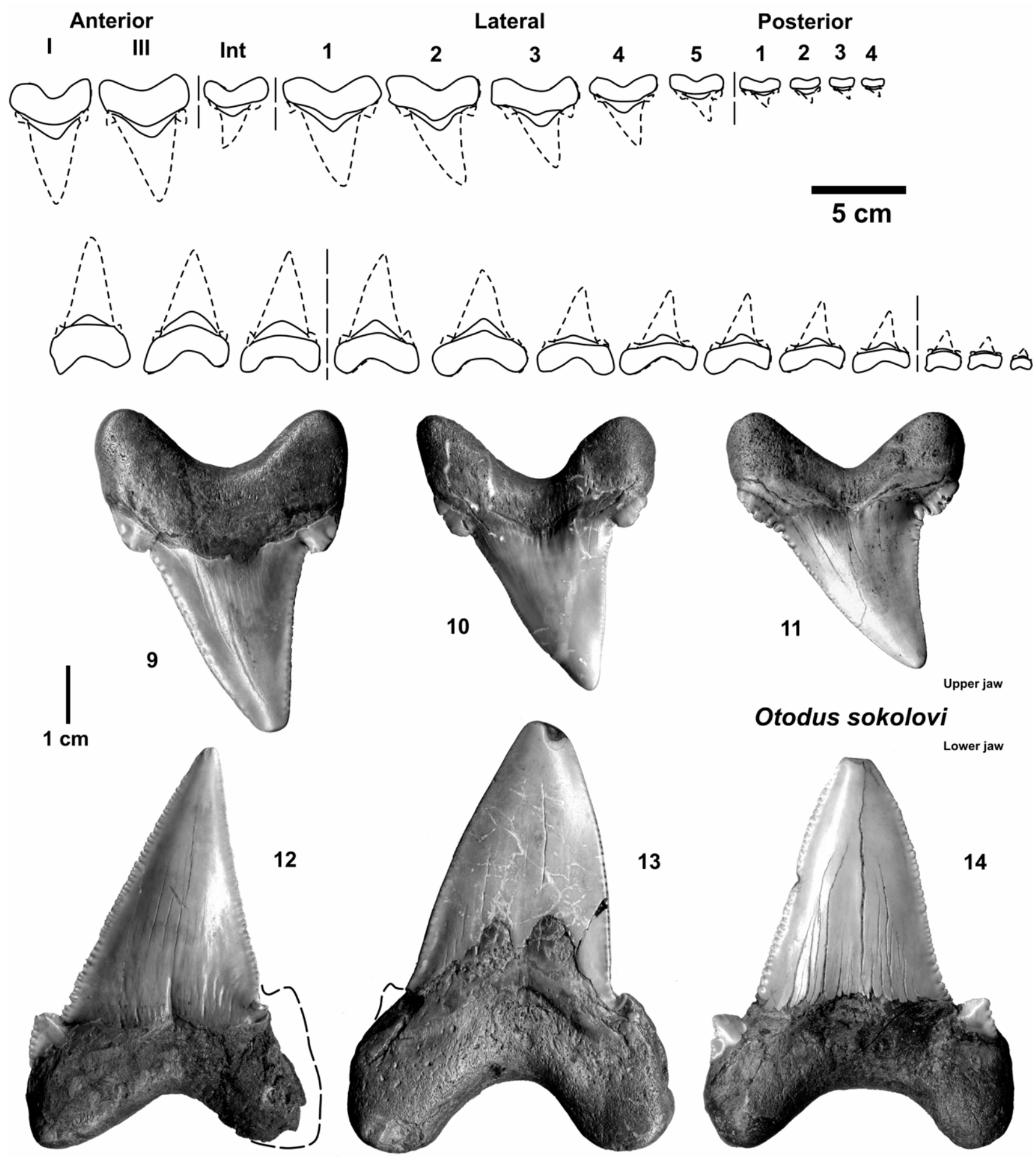

Figure 4. Parts of tooth sets from the megatooth shark ancestor Otodus sokolovi (9 - 12 coll. HF) from the early Middle Eocene (Lutetian) gravels of Dalum, north-western Germany, which also include reworked Late Paleocene to Early Eocene material (all in the $\mathrm{SCB})$.

teeth (=first serration wave) [19], from Carcharodon orientalis (Snizow 1899) a former genus "Procarcharodon", or synonymous to "C. landanensis Lériche, 1910"), having been found in upwelling-influenced phospaticrich sediments of Morocco [7, Figure 2]. These teeth belong to the "small serrated tooth" type, with primitive coarse serration on all teeth as well as flattened roots in all lateral to posterior teeth which is, as mentioned, the most important character for distinguishing the megatooth sharks from white sharks on the basis of tooth 
morphology. This is also important for understanding the origin of white sharks from Isurus. The most abundant white shark ancestor tooth material is slightly younger and comes from sites in north-western Germany [10], ranging in age from Early Eocene to early Middle Eocene and includes the more highly evolved Carcharodon auriculatus (Blainville, 1818) which occurs around the world [19,20, Figure 1], and to which also belong $C$. disauris - (Agasiz 1843), C. debrayi (Lériche 1906), and C. nodai (Yabumoto 1987) [20]. The large quantities of teeth recovered allow presenting nearly complete sets of teeth can be compiled according to known articulated toth sets (Figures 3 and 4). A finer serration had already evolved by this time, although some teeth still exhibit coarser serration (in adult teeth), especially the lateral cusplets. The roots are still typically prominent in anterior teeth, but are flattened in all lateral to posterior teeth, typical also in Isurus teeth. This species is followed in the Oligocene by Carcharodon subserratus, and in the Lower Miocene by Carcharodon gibbesi (Figure 1) which transitions to the extant Carcharodon carcharias, but their remains are not yet well known due to the absence of tooth sets from those periods.

There is a general evolutionary trend in the tooth morphology of Carcharodon (Figure 1). During the Late Eocene to Late Miocene the lateral cusplets were reduced and the tooth crowns became a little enlarged, a convergent development with that of the megatooth lineage.

The same trend has also been reported in the Late Cretaceous, when Isurus (formerly Cretoxyrhina) tooth cusplets became reduced the crowns enlarged in a similar way, as an adaptation for shark predation on the evolving mosasaurs and other marine reptiles at this time (Figure 1) [21]. This first Isurus adaptation for feeding on large marine prey thus evolved in the Cenomanian (I. denticulatus), in the early part of the Late Cretaceous, while the lateral cusplets were reduced during the Turonian resulting in enlarged teeth with no cusplets in the Coniacian ( $I$. mantelli), paralleling the evolution and diversification of the mosasaurs [21]. A second adaptation in tooth morphology appears to have been related obviously to Tertiary mammal radiation as presented herein (Figure 2).

That modern white sharks evolved from the Paleocene Carcharodon orientalis (first serration wave) can also be recognized from the ontogenetic tooth stage repetition in C. carcharias. The teeth of immature individuals are initially coarsely serrated (very similar to C. orientalis) but became more finely serrated in adult sharks [14]. Serrations can even sometimes be absent in teeth from $C$. carcharias [22], which may also be indicative of ancestors without serrated teeth (i.e. Isurus). Another form (I. escheri) with slightly serrated teeth evolved from Isurus in Miocene to Pliocene times (= second serration wave) $[17,18]$, as a third adaptation to the type of prey, this time in response to marine mammal diversification during the
Middle Miocene (Figure 1: 3rd radiation of marine mammals, including the appearance of modern dolphins), which provides further evidence that the genus Isurus, was also before the ancestor of Carcharodon (Figure 1).

\subsection{Megatooth Shark-Otodus Lineage}

The oldest of these largest serrated teeth are more closely related to Otodus and finally also to Lamna, contrary to suggestions by other authors $[1,13]$, and therefore O. obliquus (Agassiz, 1843) must be seen, as the oldest representative of megatoth sharks that developed also serrated teeth (as has also been proposed by other authors [5]), which strictly should be referred not to the invalid to "Carcharocles" genus, instead Otodus. These younger forms separating it especially from serrulation absence (also dentition formula few differences) are herein suggested only to be ancestral to the megatooth shark lineage (Figure 2), which exclusion is explained within the Isurus lineage and revision of Upper Cretaceous species [21]. "Carcharocles" is indeed a subjective younger synonym of Carcharodon (C. auriculatus, see white shark discussion) and cannot be used therefore for any other species anymore. This has an effect on the renaming herein several megatooth shark species conesquently. Using this, all megatooth sharks from non serrated to full serrated teeth stages must be named as Otodus Agassiz, 1843 as the oldest genus name.

The new material from Germany (Figure 4) also contains reworked Paleocene to Early Eocene fossils [10], and it appears obvious that the full transition from nonserrated Otodus to slightly serrated "Otodus" forms can be supported through compiled tooth sets also of the German sites [cf. 10]. This evolution, involving the general development of serrations, has also been recorded from the eastern Tethys (Kazakhstan), but there, both lineages have been incorrectly interpreted as belonging to a single white shark lineage and were therefore mixed [19]. However, around the world the first serrations on Otodus teeth appear on teeth (anterior to posterior) with massive roots, which are herein placed within the genus Otodus subserratus Agassiz, 1843 [4] (also with other species names of aksuaticus, and mugodzharicus [4]). Following the better eastern Tethys stratigraphic record, O. subserratus first appeared in the late Thanetian (Late Paleocene) and continued into the middle Ypresian (Early Eocene; Figure 2) [19]. Similar O. subserratus teeth from the Eocene of Germany again provide evidence for this gradual transition from non-serrated Otodus teeth with massive roots $(O$. obliquus, Danian to early Thanetian) to early Otodus serrated teeth (O. subserratus, late Thanetian to middle Ypresian) again in a "short-time" frame. This has also been previously proposed by a number of authors but therein with the different genus names Carcharocles/Carcharodon [4, and references therein]. 
The first fully serrated megatooth shark teeth must have already been developed by the late Ypresian [19]. The material from the Middle Eocene condensed gravels of northwest Germany includes the oldest known and well dated not younger as middle Lutetian records of Otodus sokolovi (Jaeckel, 1895) [10] (Figures 1 and 2), extending its chronostratigraphic occurrence between the Middle Eocene and the Early Oligocene [13] (Figure 1). Complete sets of teeth would be required from this time frame to distinguish this new Middle Eocene material from younger forms. Some of the individual teeth collected in Europe from the Late Oligocene to Early Miocene "O. angustidens" must be ascribed to the Rupelian (Early Oligocene) species O. sokolovi (Figures 1 and 2), as seen in the material compared herein from the proto North Sea Basin (German localities at Eckelsheim and Espenhain). O. angustidens (Agassiz, 1843), which is known from isolated teeth from the northwest German Doberg site (Late Oligocene, proto North Sea Basin) [12, 13]. Proof of this lateral cusplets reduction is found in the complete tooth set and partial $O$. angustidens skeleton found in Ne Zealand, which either no longer has any clearly developed cusplets on the anterior teeth (or else they are very flattened), but which still has cusplets present on the more lateral and posterior teeth [7].

This tooth set represents the transition between teeth with lateral cusplets and those with either flattened cusplets or no cusps at all (Figures 2 and 4). The most evolved megatooth teeth are from $O$. megalodon (former "Carcharodon/Carcharocles") and have no lateral cusplets which, having been fully reduced, are completely absent from all teeth (Figure 2). Despite this is not frequent, lateral cusplets indeed appear in posterior replacement teeth during early growth stages of the tooth. There are several late Miocene-early Pliocene examples in the records along the Pacific.

In general, all non-serrated-serrated megatooth Otodus shark teeth have massive roots (anterior to posterior) that are not flattened (very different in white sharks), with fine serrations starting in the Thanetian (Late Paleocene) and a trend towards lateral cusplet reduction that started in the Early Oligocene (Figure 2: second radiation of marine mammals), ending with no lateral cusplets and enlarged "saw-blade" fine serrated tooth crowns in the Middle Miocene (Figure 2: third radiation of marine mammals). This convergent development with white shark teeth often makes them very difficult to distinguish from each other. The teeth coevolved from catching teeth to cutting teeth, driven by the three major marine mammal radiations during the Tertiary (Figure 2).

\subsection{Early Prey Specializations in Megatooth Sharks and White Sharks}

The main groups of large marine mammals can now be reported to have been present in the in the Proto North Sea Basin of Europe. The gravels at Fürstenau have yielded the remains of seals (Figure 5) [12], and also of sirenians (ribs) [13], and whales (possibly vertebrae in very fragmentary material, Figure 5(E)), all of which are found within the time frame of the first marine mammal radiation which started in the Thanetian to Ypresian of the Late Paleocene or Early Eocene (Figure 2: first radiation of marine mammals) [12]. In the megatooth and white sharks from the Early to Middle Eocene of northwest Germany, more marked damage to the tips of many changed teeth which are non-strong transported and non-rounded (Figure 5 [10]) such as in many other cases, suggests clearly damage from feeding on large robust prey such as larger bony fish, or marine mammals. Only fish remains have so far been found in the few shark coprolites preserved from the Early to Middle Eocene of Germany, which have been attributed to these large sharks [11] (Figure 5), but this is no contra-argument to exclude mammals as large shark prey at all. The chance to find in an excrement a seal, sirenian or whale bone fragment is nearly zero, because most bones (also fish) were dissolute mostly by stomach acid, or were left so small not to be identified as such. Furthermore, the recent coprolite studies on the Fürstenau shark coprolites did not allow damaging the large megatooth/white sharks attributed few specimens, where mammal bones can be expected. Not to destroy those rare specimens only bones which were visible on the excrement surface have been identified [11]. Finally, most bones built completely dissolute the phosphate matrix of the coprolites. The arguments given herein are more a combination of shark tooth tip damage, and co-occurrence with the "marine mammal fauna" such as:

Seals: The oldest Praephoca seal records from northwest Germany (Lutetian, early Middle Eocene, Figure 5) pushed back the time from Lower Oligocene to Middle Eocene when they could have been first predated by large sharks. Former fossil finds previously suggested seals to have been present not before the Late Oligocene [2], whereas DNA studies also proposed clearly the origin of pinnipeds already in the Eocene [22]. Large seal populations appear to have bread at the Middle Eocene's sandy beaches along the southern coastline of the proto North Sea Basin in Central Europe. This is estimated by the fossil record and taphonomy of pinipeds, which is recently studied for the Eocene to Pleistocene seal evolution and record of the Proto North Sea Basin [cf. 12]. Interestingly, in $99 \%$ of the fossil records of Eocene, and Miocene shark-tooth-boenbeds the seal remains (always less then $0.1 \%$ of the vertebrates) consist of the longbones (mainly humerus and femur) and other massive bones, teeth are e.g. known by a single record. Furthermore the amount of seal remains was estimated per 100 cubique meter of the gravels where they were found 

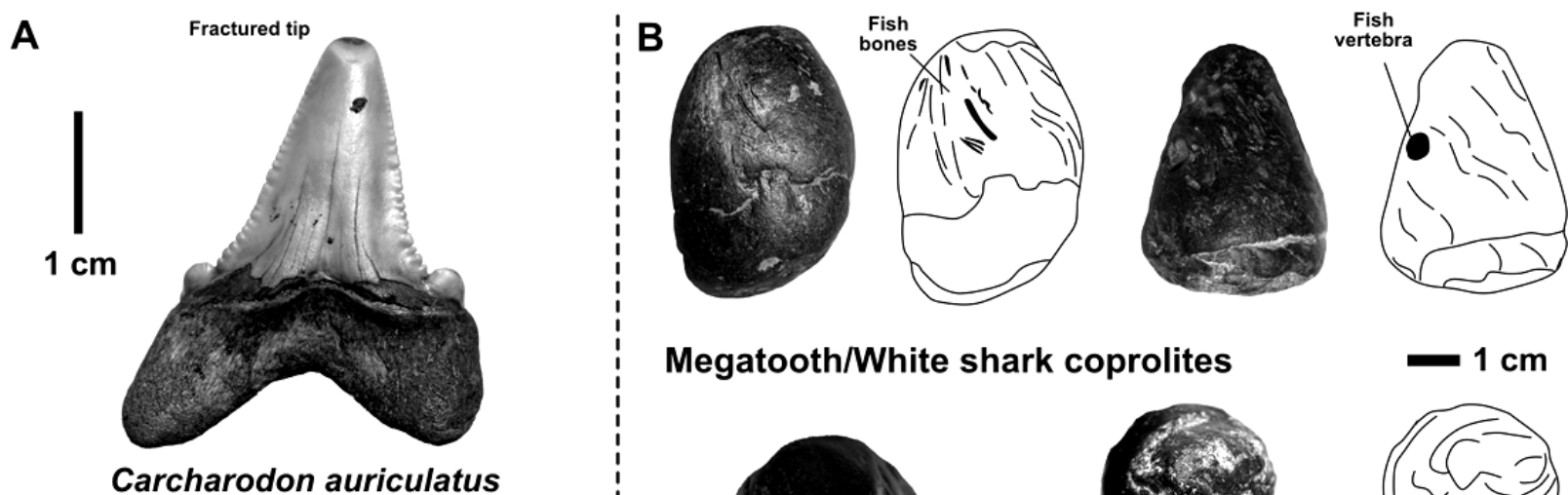

\section{Megatooth/White shark coprolites}
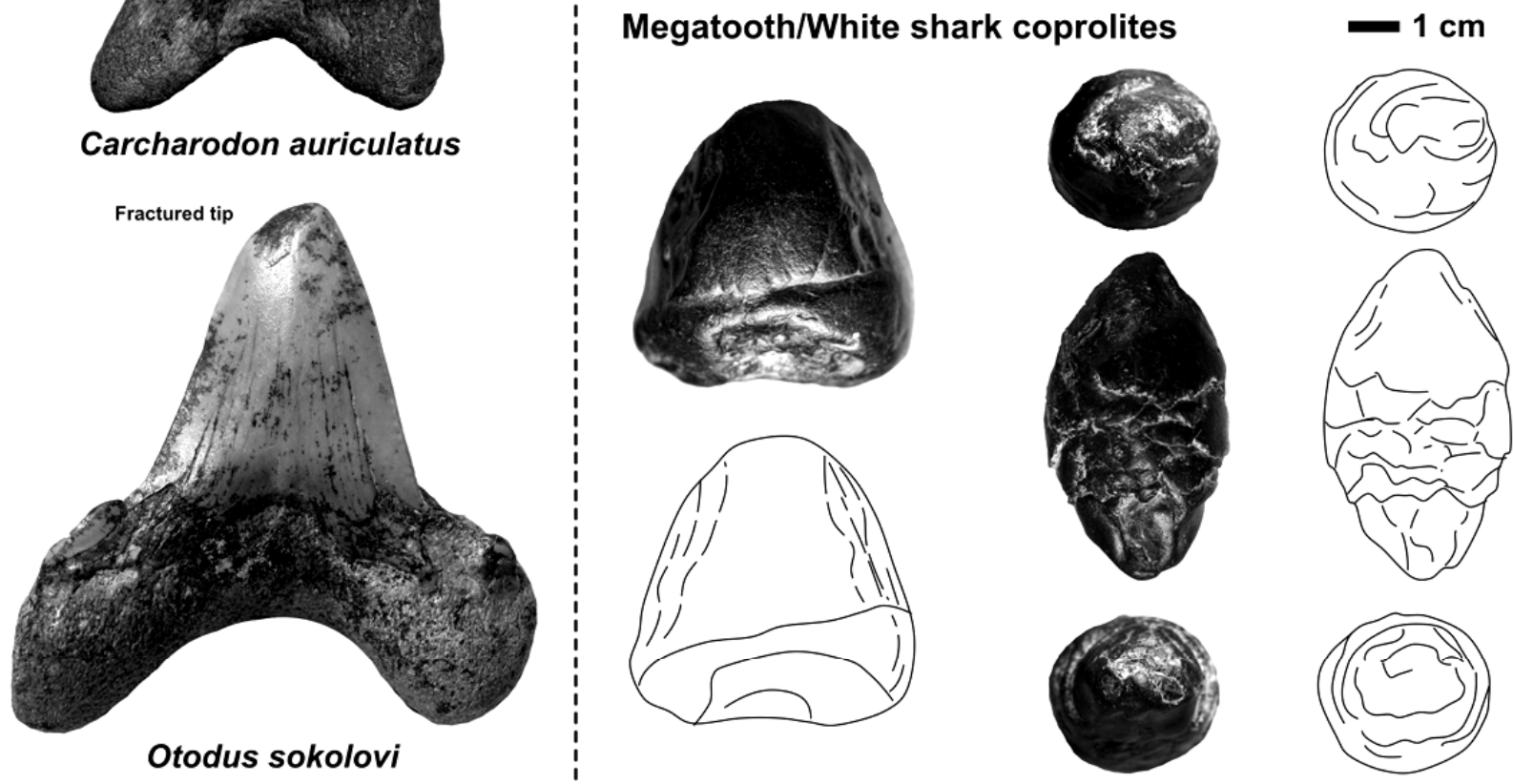

Otodus sokolovi

C
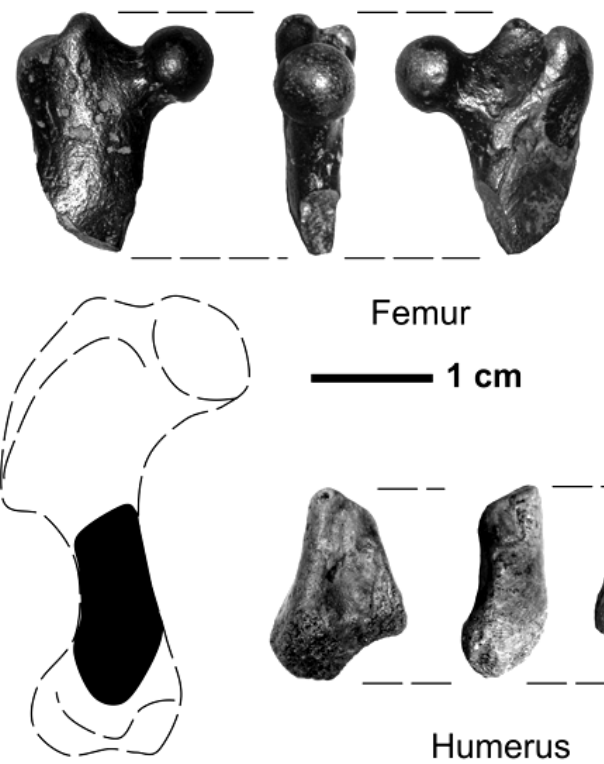

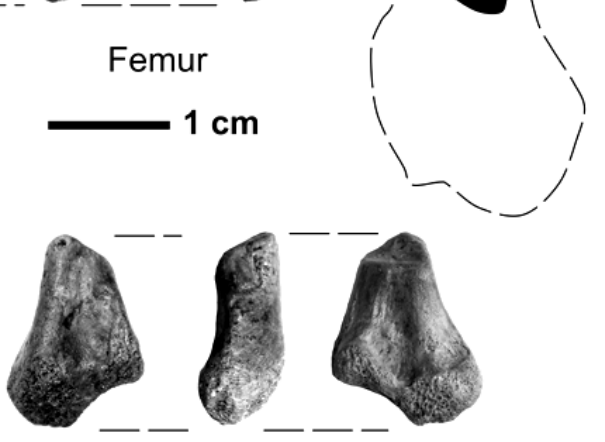

Humerus
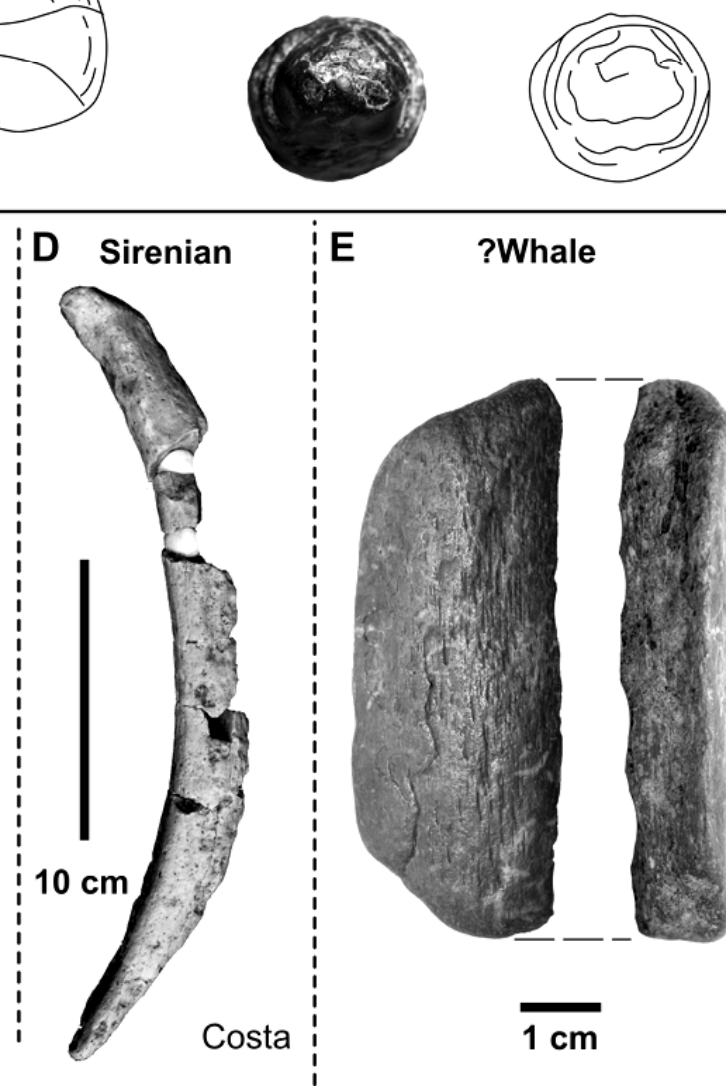

E ?Whale

Figure 5. A) Bite damage on the tips of teeth from megatooth and white shark ancestors Carcharodon auriculatus and Otodus sokolovi (coll. SCB); B) Large coprolites from the Middle Eocene Dalum and Osteroden near Fürstenau sites (coll. HF), which contain only fish remains, can be attributed to these large sharks; C) Seal bone remains from the Middle Eocene Dalum site, femur fragment from [12]; D) Protosiren sp. rib from the Middle Eocene Dalum site (coll. HF), from [13]; E) Possible ?whale bone fragment remain from the Middle Eocene Dalum site (coll. SCB) (all in the SCB). 
(Eocene, Miocene shark-bonebed gravels) where less then 1 specimen is found. The relation is about 1 seal remain to 250,000 shark teeth remains, e.g. at the Fürstenau (Germany) Eocene site, or the Rumst (Belgium) Miocene site. Even the Pleistocen bones from the Northsea Floor (found by fisherman) are rare. Few or single bones in the fossil record, therefore, can indeed indicate "larger populations", which however are represented by taphonomic sorting (e.g. most robust and larger humeri/ femorae) are more sensitive for water transport (currents), such as tiny teeth. The gravels in the Eocene/Miocene have a sorting (around $2 \mathrm{~cm}$ gravel sizes) - and this water energy sorting might explain best the scarcity of "larger seal bones" and their sorting in shark-tooth-rich gravels in the Proto North Sea Basin. In the shallow shelf sediments of Fürstenau Carcharodon auriculatus teeth are the second most abundant (455 specimens $=7 \%$, Figure 1) after sand shark (Striatolamia macrota) teeth (5901 specimens $=85 \%$ ), based on a total of 6946 systematically excavated teeth [10]. At other sites in Belgium that are rich in shark teeth but from which marine mammals have not yet been reported [20], C. auriculatus teeth are present in much smaller quantities (not statistically presented) in the coastal sands [20]. The correlation between the occurrence of seals and abundant teeth from the white shark ancestor C. auriculatus provides the main evidence of the oldest known seal-hunting specialization in the fossil record of the northern hemisphere. Sharks probably hunted along the seals' breeding beaches (Figure 1) in much the same way that modern sharks do (Figure 5) [23]. Sadly, there are no comparative taphonomic studied that demonstrate the modern abundancy of seal bones and shark teeth at modern seal breeding beaches. Small white shark ancestor teeth are also abundant at more recent fossil sites in other parts of the world in which seals have been recorded [24], especially in cold marine regions influenced by upwelling [1]. Even today, seal hunts fulfil an important role in the feeding of mature white sharks. Whereas immature white sharks (up to 2 meters in length) feed mainly on fish, as well as on other sharks, when they reach adulthood they switch to seal hunting [25]. Such predation on seals has best been documented in seal colonies along the coast of California [23]. The photo sequence of great white sharks hunting the cape fur seal Arctocephalus pusillus on the South African coast, (Figure 5) demonstrates their attack technique, in which the white sharks generally attack from below, throwing the seal prey out of the water (Figure 5) [23] and then biting into any part of the body to prevent their agile prey escaping [23].

Sirenians: were reported with oldest Early Eocene (Pezosiren) to basal Middle Eocene (Prorastomus) forms from Jamaica and the Caribbean [26-30]. The new model of polyphyletic evolution split now the siren origins with manatees in the Caribbean Central America (basal Early
Eocene), and dugongs on the northern African Tethys coasts (early Middle Eocene) [13].

In the Lutetian only Protosiren was distributed within the Thetyan realm represented possibly even by a few species around the warmer Tethys oceans, only (Figure 1) [13]. The newly discovered Protosiren rib and further fragments from the early Middle Eocene proto North Sea Basin conglomerates of Fürstenau correlate with the influence of warm Tethys water and megatooth shark migration for predation. In younger Early Oligocene horizons of Europe several fossil sirenian Halitherium skeletons document by bite scratch marks on ribs/vertebrae that these animals were quite commonly scavenged by sharks, and probably even killed by warm water species such as $O$. angustidens in the Rhine Graben, the Proto North Sea Basin [31], and the Alpine Molasse Basin [32] of Europe.

Whales: Primitive archaeoceti toothed whales (the Pakicetidae, Ambulocetidae) were first recorded from the Thanetian/Ypresian (Early Eocene), and with the first radiation and Remingtoncetidae which developed in the Early to Middle Eocene (Figure 1) [33-50]. During the early Middle Eocene (Lutetian) at least four whales (or groups) were present around the world, although again only in warm oceans, these being Ambulocetus, Indicatus, Maiacetus and Aegyptocetus [36-38,42,49]. Well known discoveries of Basilosaurus skeletons have been reported from Australia and Egypt, within marine sediments of Upper Eocene age [51-53]. Some "archaeocetid whale" bone fragments from Fürstenau [13] might represent the most northern records of these mammals (Figure 1), but more finds from Fürstenau must confirm this in future. The whale and megatooth shark distributions again overlap globally, both being present in shallow coastal shelf zones of the Tethys realm, and the northern southern hemisphere (Figure 1) [54,55]. Megatooth sharks $(O$. subseratus, and O. sokolovi, Figure 2) also coevolved with their largest whale/sirenian prey during the Thanetian and Lutetian (Late Paleocene to Early Eocene; Figures 1 and 2). The oldest record of their feeding on whale carcasses is evidenced by large shark bite marks on the thoracic region (ribs) of Aegyptocetus tarfa, a middle Eocene archaeocetid from Egypt [49]. Similar tooth marks on immature whales are also known from younger Pliocene strata [56], but these appear to have been produced by megatooth sharks, and not by white sharks as has previously been speculatively reported. Similar large bite damage also appears on Pliocene whale vertebrae from the east coast of North America [1]. Modern white sharks are known to have taken over the ecological niche of megatooth sharks, and to also scavenge on whales all around the world [25].

Dolphins with modern forms appeared as far as we know up to date during the Middle/Late Miocene (Serravalian/Tortonian) [42] and then spread around the 
world (Figure 1). From the Miocene to the Pleistocene their main shark predators were O. megalodon (until its extinction in Pleistocene) and C. carcharias. In addition to these sharks, a separate evolution with secondary and not to the C. carcharias lineage developing tooth-serration development clearly took place within the Isurus lineage during this period, from I. hastalis to I. escheri (Figure 2) [17], which are not seen herein as the ancestors of the modern white sharks (being another serrulation process, different seen in [17]). The radiation of modern dolphins (3rd radiation of marine mammals, Figure 2) and other marine mammals was probably the motor behind the prey-related adaptations and tooth morphology changes in large scavengers on marine mammals. There is one fossil dolphin recorded as showing evidence of scavenging, in the form of large shark bite marks; this specimen is from the Pliocene of southern Europe [57].

\subsection{Prey Migrations, Water Temperatures, and Shark Paleobiogeography}

The new sieving of Middle Eocene material from northwest Germany yielded 2 teeth from the German megatooth shark O. sokolovi [10] (but more then 100 larger teeth are present from another collection of HF), supporting the theory, that megatooth sharks in general were occasionally present in colder oceans/waters and may have migrated through these upwelling and temperate basin areas [1]. The O. sokolovi megatooth sharks were far less abundant ( 2 teeth recovered) in the Eocene proto North Sea Basin than the C. auriculatus white sharks (455 teeth recovered) [10]. The megatooth sharks may have followed large, migratory mammal prey such as whales and sirenians, which are likely to have made use of the seasonal warm surface-water currents of the Tethys for north- and east-westward migration (Figure 1). Further support for this theory can be found in the same region, but from the Late Oligocene. The northern German Doberg fauna contains remains of the toothed whale Eosqualodon, as well as remains of the siren Anomotherium [31] and the large teeth from its megatooth shark predator $O$. angustidens [13], but white shark teeth are unknown in the Late Oligocene of northern Germany, yet, also because there are shark-tooth enriched condensation bonebeds absent (teeth are "rare"). Thus the abundant white shark C. auriculatus must have lived in cold-water areas of upwelling, as demonstrated in the Proto North Sea Basin [10]. This temperature control on the distribution of these predatory sharks has also been recorded in more recent periods (extending from the Oligocene to the Pliocene) all around the world [1]. There is a clear correlation in the fossil record between the scarcity of both, megatooth shark ancestors and their prey (whales and sirenians) [1] in areas of cold water upwelling, and the abundance of white sharks, together with seals in some of those areas [1], such as demonstrated herein for the Proto North Sea basin of Europe.

\section{RESULTS}

The early white shark Carcharodon auriculatus and the megatooth shark Otodus sokolovi were both present in the European proto North Sea Basin about 47.8 - 41.3 m.y. ago (Lutetian, early Middle Eocene), as well as in the Tethys realm only around the world. At the same time, early seals may have been common in cold waters, and remains of a few rare early warm water adapted sirenians and basal toothed whales are known from the sandy beach areas and shelf regions of the proto North Sea Basin, which had primary cold water temperatures and was influenced by upwellings but was also subject to the periodic influence of warm surface waters from the Tethys realm.

The new excavated serrated teeth presented from the German Eocene (Lutetian) are not of one species, nor do they only represent different individual ages of one species. Compared to modern white shark ontogenetic tooth morphology stages, the juvenile teeth in white sharks are much more coarsely serrated first, and the later are more densely - which is studied in the fossil record only for the fossil Palaeocene white shark forms partly. Another and most important character is the root form, massive-thick in Otodus and thin-flattened in Carcharodon (anterior teeth that are intermediate and more difficult to separate) - a main character, that distinguishes the similar serrated teeth (especially lateral ones) of grown up individuals in several cases, and which ontogenetic stages of Eocene species remain unclear. These similar looking serrated teeth exactly confused their separation in the past, but their maximum size in each genus also differs much being nearly twice large in Eocene Otodus with up to $8 \mathrm{~cm}$ height teeth fitting to the known general body sizes of white and megatooth sharks finally.

The two types of giant sharks, which were the main predators along these coastlines, were polyphyletic with two different lamnid shark ancestors within the Early Paleocene to Early Eocene time-span, which are Carcharodon (Isurus - white shark lineage) and Otodus (Lamna-megatooth shark lineage). Both, megatooth and white shark lineages exhibited convergent serrated saw-blade teeth, but with different (massive or non-massive) roots in the lateral teeth, different dental formulas, and different maximal sizes. The "saw-blade" teeth were the result of adaptation to feeding on various marine mammals, and their development coinciding with the emergence of seals, sirenians, and whales in parallel with the evolution of these large predatory sharks during the Late Paleocene to Early Eocene.

Megatooth sharks specialized in hunting whales and sirenians on the coastal shelves of warm oceans, but also migrated with warm surface currents into northern areas 
of upwelling in which fishes were abundant, which has been shown from the northernmost records of the Proto North Sea Basin shelf, in northern Europe.

The white sharks, however, were adapted to cold and temperate waters. While the immature white sharks may have hunted in fish-rich areas, the adult sharks must have fed mainly on the early seal populations, along the coas lines of their reproduction beaches which also appear to have been located in cool to temperate waters (southern proto North Sea Basin). This specialization of white sharks in hunting seals, especially in the vicinity of seal colonies, has continued to the present, for example with the great white sharks hunting seals along the Californian and South African coastlines (Figure 6).
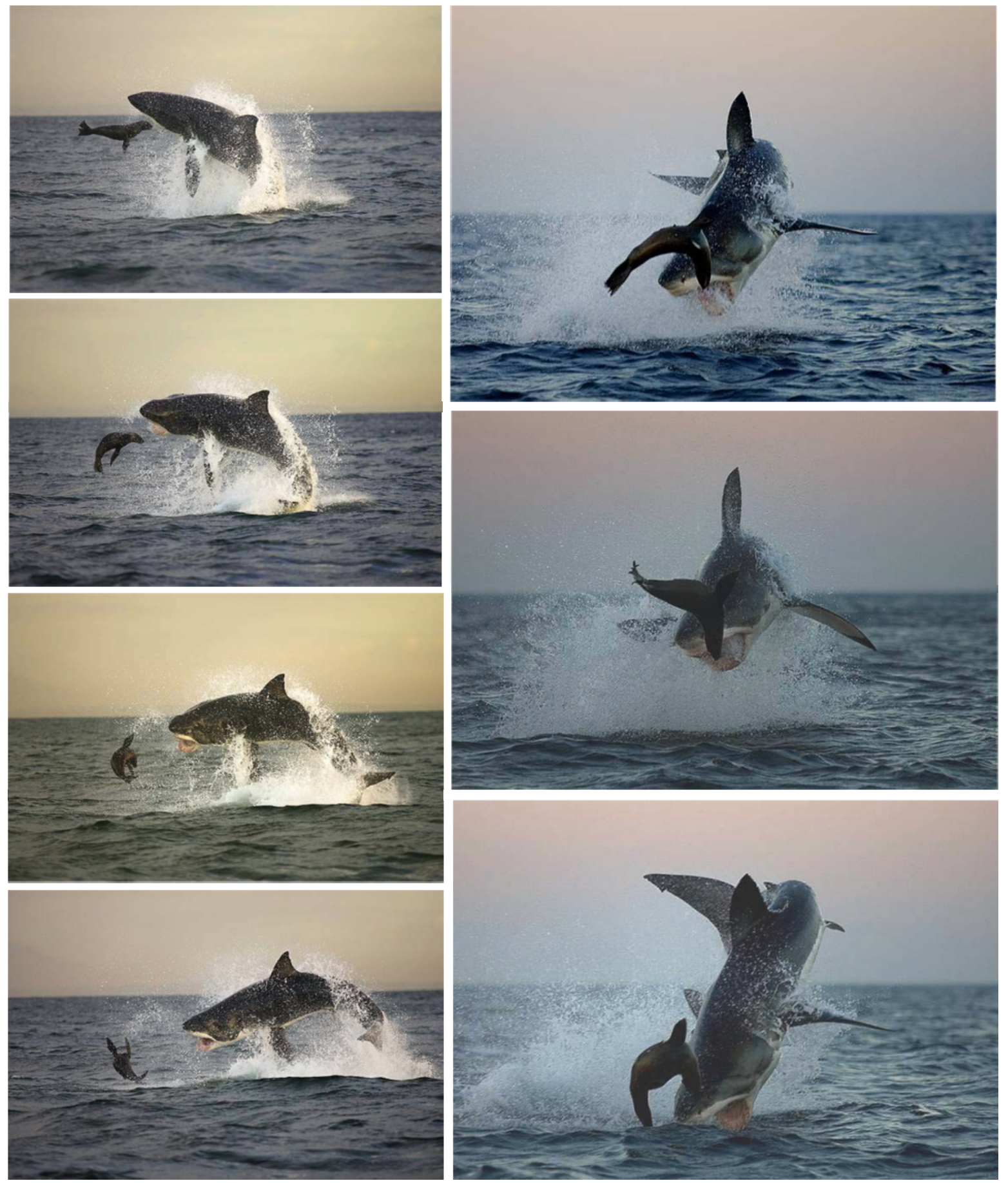

Figure 6. Photographic sequences of a modern white shark Carcharodon carcharis hunting a cape fur seal Arctocephalus pusillus in warm waters along the South African coast (Photos C. \& M. Fallows). 
With a second marine mammal radiation in the midOligocene and a third radiation during the Middle Miocene, the tooth morphology of megatooth sharks and white sharks developed further, with both lineages again showing similar types of adaptation. The lateral tooth cusplets became smaller, while oppositely the crown base widened and even the overall tooth size enlarged (= "saw blade type"), but this development was much more marked in the megatooth sharks, as they grew in size proportional to their large whale prey during the Neogene, during which time whales became larger, marine mammals radiated once again, and the modern dolphins emerged (in the Serravallian/Tortonian of the Middle/ Late Miocene). In parallel with the third marine mammal radiation, a secondary serration evolution again took place again in "short-term" within the Isurus lineage (from I. hastalis to I. escheri), which later became extinct at the beginning of the Pleistocene "Ice Age", as did the megatooth sharks.

Whereas the warm-water adapted megatooth sharks disappeared globally in the Pleistocene due to climate change and ocean cooling, the cold-water adapted white sharks have survived more than $57 \mathrm{~m}$.y. until the present day as specialized coastal seal hunters. Adult great white sharks today feed on modern seals in temperate to warm seawaters, indicating that they must have modified their habitat during the Ice Age, and even their body temperatures, to take over the niche vacated by the extinction of the megatooth sharks. Mature individuals now also feed on whales and sirenians but still predominantly on seals, as they have started to feed on a new marine mammal prey source for more than 50 million years.

\section{ACKNOWLEDGEMENTS}

The excavation project was sponsored by the Geopark TERRA.Vita, and the Osnabrück Landkreis. The company PaleoLogic was responseble for the field work and scientific research and its funding. I am grateful to The Kuhlhoff education center leaders (Mr. A. Bruns and Mr. W. Hollermann), and the mayor of Bippen, Mr. H. Tolsdorf, for managing the installation of a field sieving laboratory. I would also like to thank H. Felker, a local hobby-palaeontologist, who provided support, helped with sieving the material, and allowed access to his large sharktooth collection obtained over 25 years from both Dalum and Bippen localities for comparisons, especially of the white shark tooth material. Finally E. Manning supported much with the spell-check. Finally, I am grateful to C. and M. Fallows for permission to use their photos. Finally I thank the reviewers, such as Dr. R.W. Boessenecker, for their critical comments of the former drafts.

\section{REFERENCES}

[1] Purdy, R. (1996) Paleoecology of fossil white sharks. In: Kimley, A.P. and Ainley, D.G., Eds., Great White Sharks:
The Biology of Carcharodon carcharias, Academic Press, San Diego, 67-78.

http://dx.doi.org/10.1016/B978-012415031-7/50009-4

[2] Long, D.J. and Waggoner, B.M. (1996) Evolutionary relationships of White Shark: A phylogeny of lamniform sharks based on dental morphology. In: Kimley, A.P. and Ainley, D.G., Eds., Great White Sharks-The Biology of Carcharodon carcharias, Academic Press, San Diego, 3334. http://dx.doi.org/10.1016/B978-012415031-7/50006-9

[3] Martin, A. (1996) Systematics of the lamnidae and the origination time of Carcharodon carcharias inferred from the comparative analysis of mitochondrial DNA sequences. In: Kimley, A.P. and Ainley, D.G., Eds., Great White Sharks: The Biology of Carcharodon carcharias, Academic Press, San Diego, 67-78. http://dx.doi.org/10.1016/B978-012415031-7/50007-0

[4] Bourdon, J., Ward, D. and Grimsley, G. (2000) The development of serrations on Otodus (Agassiz 1843) (Selachii: Otodontidae) teeth during the Early Eocene-The transition from Otodus obliquus (Agassiz, 1843) to Carcharocles auriculatus (Blainville 1818);

http://www.elasmo.com/genera/slides/o_lineage/o_segue. $\underline{\mathrm{html}}$

[5] Storms, M. (1926) Sur un Carcharodon du terrain Bruxellien. Sociéte. Belgique Geologique Paleontologie et Hydrologie, II T, 5, 201-213.

[6] Lériche, M. (1901) Les poisons Neogene de la Belgique. Musée Royal Histoire Naturelle Belgique Memoires, 32, 368-472.

[7] Gottfried, M.D. and Fordyce, E. (2001) An associated specimen of Carcharodon angustidens (Chondrichthyes, Lamnidae) from the Late Oligocene of New Zealand, with comments on Carcharodon interrelationships. Journal of Vertebrate Paleontology, 21, 730-739.

http://dx.doi.org/10.1671/0272-4634(2001)021[0730:AA SOCA]2.0.CO;2

[8] Uyeno, T., Sakamoto, O. and Sekine, H. (1989) The description of an almost complete tooth set of Carcharodon megalodon from a Middle Miocene bed in Saitama Prefecture, Japan. Saitama Museum of Natural History Bulletin, 7, 73-85.

[9] Ehret, D.J., Hubbell, G., Macfadden, B.J. (2009) Exceptional preservation of the White Shark Carcharodon (Lamniformes, Lamnidae) from the Early Pliocene of Peru. Journal of Vertebrate Paleontology, 29, 1-13. http://dx.doi.org/10.1671/039.029.0113

[10] Diedrich, C. (2012) Middle Eocene (Lutetian) coastal shark-rich palaeoenvironments of the southern European North Sea Basin-The marine Fürstenau Fm biodiversity and their earliest white shark ancestors. International Journal of Oceanography, 2012, 1-22. http://dx.doi.org/10.1155/2012/565326

[11] Diedrich, C.G. and Felker, H. (2012) Middle Eocene shark coprolites from shallow marine and Deltaic coasts of the pre-North Sea Basin in Central Europe. New Mexico Museum of Natural History and Science, Bulletin, 57, 311-318.

[12] Diedrich, C. (2011) The world's oldest fossil seal record. 
Natural Science, 3, 914-920.

http://dx.doi.org/10.4236/ns.2011.311117

[13] Diedrich, C. (2013) Most northern Protosiren siren records in the European Pre-Northsea Basin and the polypheletic evolution of manatees and dugongs. Natural Science, in press.

[14] Applegate, S.P. and Espinosa-Arrubarrena, L. (1996) The fossil history of Carcharodon and its possible ancestor, Cretolamna: A study in tooth identification. In: Kimley, A.P. and Ainley, D.G., Eds., Great White Sharks: The Biology of Carcharodon carcharias, Academic Press, San Diego, 19-36. http://dx.doi.org/10.1016/B978-012415031-7/50005-7

[15] Schwarzhans, W. (2007) The otoliths from the middle Eocene of Osteroden near Bramsche, north-western Germany. N. Jahrbuch für Geologie und Palaeontologie Abhandlungen, 244, 299-369. http://dx.doi.org/10.1127/0077-7749/2007/0244-0299

[16] Cappetta, H. (2012) Chondrichthyes. Mesozoic and Cenozoic Elasmobranchii: Teeth. Pfeil-Verlag, Munich, 512 p.

[17] Ehret, D.J, Macfadden, B.J., Jones, D.S., Devries, T.J., Foster, D.A. and Sales-Gismond, R. (2012) Origin of the white shark Carcharodon (Lamniformes: Lamnidae) based on recalibration of the Upper Neogene Pisco Formation of Peru. Palaeontology, 55, 1139-1153.

[18] Stewart, J.D. and Raschke, R. (1999) Correlation of stratigraphic position with Isurus - Carcharodon tooth serration size in the Capistrano Formation, and its implications for the ancestry of Carcharodon carcharias. Journal of Vertebrate Paleontology, 19, 78A.

[19] Zhelezko, V.I. and Kozlov, V.A. (1999) Elasmobranhii i biostratigraphia paleogena Zauralia i Srednei Asii (Elasmobranchii and Palaeogene biostratigraphy of Transural and Central Asia). Materialy po stratigrafii i paleontologii Urala, 3, 1-324.

[20] Van den Eeckhaut, G. and De Schutter, P. (2009) The Elasmobranch fauna of the Lede Sand Formation at Osterzele (Lutetian, Middle Eocene of Belgium). Palaeofocus, 1, 1-57.

[21] Diedrich, C. (2013) The oldest neoselachian Isurus denticulatus (Glückmann) skeleton from the Late Turonian (Upper Creteceous) of Germany and a revision of the genus Cretoxyrhina. ISRN Paleontology, in press.

[22] Fulton, T.L. and Strobeck, C. (2010) Multiple markers and multiple individuals refine true seal phylogeny and bring molecules and morphology back in line. Proceedings of the Royal Society, B, 277, 1065-1070.

[23] Long, D.J., Hanni, K., Pyle, P., Roletto, J., Jones, R. and Bandar, R. (1996) White shark predation on four pinniped species in Central California waters: Geographic and temporal patterns inferred from wounded carcasses. In: Klimley, A.P. and Ainley, D.G., Eds., Great White Sharks: The Biology of Carcharodon carcharias, Academic Press, San Diego, 263-274. http://dx.doi.org/10.1016/B978-012415031-7/50025-2

[24] Deméré, T.A., Berta, A. and Adam P.J. (2003) Pinnipedimorph evolutionary biogeography. Bulletin of the American Museum Natural History, 279, 32-76.
http://dx.doi.org/10.1206/0003-0090(2003)279<0032:C $>$ 2.0.CO;2

[25] Long, D.J. and Jones, R.E. (1996) White shark predation and scavenging on cetaceans in the Eastern North pacific Ocean. In: Kimley, A.P. and Ainley, D.G., Eds., Great White Sharks: The Biology of Carcharodon carcharias, Academic Press, San Diego, 293-307. http://dx.doi.org/10.1016/B978-012415031-7/50028-8

[26] Domning, D.P. and Gingerich, P.D. (1994) Protosiren smithae, new species (Mammalia, Sirenia) from the late Middle Eocene of Wadi Hitan, Egypt. Contributions of the Museum of Paleontology of the University Michigan, 29, 69-87.

[27] Domning, D.P. (2001) The earliest known fully quadrupedal sirenian. Nature, 413, 625-627. http://dx.doi.org/10.1038/35098072

[28] Domning, D.P. (2001) Evolution of the Sirania and Dsmostylia. In: Mazin, J.M. and de Buffrénil, V., Eds., Secondary Adaptation of Tetrapods to Life in Water, PfeilVerlag, Munich, 151-167.

[29] Beatty, B.L. and Geisler J.H. (2010) A stratigraphically precise record of Protosiren (Protosirenidae, Sirenia) from North America. Neues Jahrbuch für Geologie und Palaeontologie Abhandlungen, 258, 185-194. http://dx.doi.org/10.1127/0077-7749/2010/0095

[30] Zalmout, I.S., Ul-Haq, M. and Gingerich, P.D. (2003) New species of Protosiren (Mammalia, Sirenia) from the early Middle Eocene of Balochistan (Pakistan). Contributions of the Museum of Paleontology of the University Michigan, 31, 79-87.

[31] Diedrich, C. (2008) The food of the miosiren Anomotherium langenwieschei (Siegfried) - Indirect proof of seaweed or seagrass by xenomorphic oyster fixation structures in the Upper Oligocene (Neogene) of the Doberg, Bünde (NW Germany) and comparisons to modern Dugong dugon (Müller) feeding strategies. Senckenbergiana Maritima, 38, 59-73. http://dx.doi.org/10.1007/BF03043869

[32] Pervesler, P., Roetzel, R. and Steininger, F. (1995) Taphonomie der Sirenen in den marinen Flachwasserablagerungen (Burgschleinitz-Formation, Eggenburgium, Untermiozän) der Gemeindesandgrube Kühnring (Niederösterreich). Jahrbuch der Geologischen Bundesandesanstallten, 138, 89-121.

[33] Dockery, D.T. and Johnston, J.E. (1986) Excavation of an archaeocete whale, Basilosaurus cetoides (Owen), from Madison, Mississippi. Mississippi Geology, 6, 1-10.

[34] Gingerich, P. D., Raza, S. M., Afif, M., Anwar, M. and Zhou, X. (1994) New whale from the Eocene of Pakistan and the origin of cetacean swimming. Nature, 368, 844847. http://dx.doi.org/10.1038/368844a0

[35] Gingerich, P.D., Wells, N.A., Russell, D.E. and Ibrahim Shah, S.M. (1983) Origin of whales in epicontinental remnant seas. Science, 220, 403-406. http://dx.doi.org/10.1126/science.220.4595.403

[36] Thewissen, J.G.M., Hussain, S.T. and Arif, M. (1994) Fossil evidence for the origin of aquatic locomotion in archaeocete whales. Science, 263, 210-212. http://dx.doi.org/10.1126/science.263.5144.210 
[37] Gingerich, P.D., Raza, S.M., Afif, M., Anwar, M. and Zhou, X. (1993) Partial skeletons of Indocetus ramani (Mammalia, Cetacea) from the lower middle eocene domanda shale in the sulaiman range of Punjab (Pakistan). Contributions of the Museum of Paleontology of the University Michigan, 28, 393-416.

[38] Gingerich, P.D., Ul-Haq, M., von Koenigswald, W., Sanders, W.J., Smith, B.H. and Zalmout, I.S. (2009) New protocetid whale from the middle eocene of Pakistan: Birth on land, precocial development, and sexual dimorphism. PLOS ONE, 4, e43-66. http://dx.doi.org/10.1371/journal.pone.0004366

[39] Uhen, M.D., Pyenson, N.D., Devries, T.J., Urbina, M. and Renne, P.R. (2011) New middle eocene whales from the Pisco basin of Peru. Journal of Paleontology, 85, 955-969. http://dx.doi.org/10.1666/10-162.1

[40] Bajpai, S. and Thewissen, J.G.M. (1998) Middle Eocene cetaceans from the Harudi and Subathu Formations of India, In: Thewissen, J.G.M., Ed., The Emergence of Whales, Plenum Press, New York, 213-234.

[41] Fitzgerald, E.M.G. (2004) A review of the Tertiary fossil Cetacea (Mammalia) localities in Australia. Memoires of the Museum of Victoria, 61, 183-208.

[42] Fordyce, R.E. (2009) Cetacean evolution, In: Perrin, W.F., Würsig, B. and Thewissen, J.G.M., Eds., Encyclopedia of marine mammals, Elsevier, Amsterdam, 201-207. http://dx.doi.org/10.1016/B978-0-12-373553-9.00053-5

[43] Geisler, J.H., Sanders, A.E. and Luo, Z.-X. (2005) A new protocetid whale (Cetacea: Archaeoceti) from the late middle Eocene of South Carolina. American Museum Novitatis, 3480, 1-65.

http://dx.doi.org/10.1206/0003-0082(2005)480[0001:AN PWCA]2.0.CO;2

[44] Gingerich, P.D., Arif, M., Bhatti, M.A. Anwar, M. and Sanders. W.J. (1997) Basilosaurus drazindai and Basiloterus hussaini, new Archaeoceti (Mammalia, Cetacea) from the middle Eocene Drazinda Formation, with a revised interpretation of ages of whale-bearing strata in the Kirthar Group of the Sulaiman Range, Punjab (Pakistan). Contributions of the Museum of Paleontology of the University Michigan, 30, 55-81.

[45] Gingerich, P.D., Arif, M. and Clyde, W.C. (1995) New archaeocetes (Mammalia, Cetacea) from the middle Eocene Domanda Formation of the Sulaiman Range, Punjab (Pakistan). Contributions of the Museum of Paleontology of the University Michigan, 29, 291-330.

[46] Gingerich, P.D., Zalmout, I.S. Ul-Haq, M. and Bhatti, M.A. (2005) Makaracetus bidens, a new protocetid archaeocete (Mammalia, Cetacea) from the early middle Eocene of Balochistan (Pakistan). Contributions of the Museum of Paleontology of the University Michigan, 31, 197-210.

[47] Uhen, M.D. (1999) New species of protocetid archaeo- cete whale, Eocetus wardii (Mammalia, Cetacea), from the middle Eocene of North Carolina. Journal of Paleontology, 73, 512-528.

[48] Uhen, M.D. (2004) Form, function, and anatomy of Dorudon atrox (Mammalia, Cetacea): An archaeocete from the middle to late Eocene of Egypt. Museum of Paleontology of the University Michigan Papers in Paleontology, 34, 1-222.

[49] Bianucci, G. and Gingerich, P.D. (2011) Aegyptocetus tarfa, n. gen. et sp. (Mammalia, Cetacea), from the middle Eocene of Egypt: Clinorhynchy, olfaction, and hearing in a protocetid whale. Journal of Vertebrate Paleontology, 31, 1173-1188.

http://dx.doi.org/10.1080/02724634.2011.607985

[50] Steeman, M.E. (2009) Radiation of extant cetaceans driven by restructuring of the oceans. Systematic Biology, 58, 573-585. http://dx.doi.org/10.1093/sysbio/syp060

[51] Domning, D. and List, P.A. (1969) Bibliography, and Index of Fossil Vertebrates of Louisiana and Mississippi. Transactions of the Gulf Coast Association of the Geological Society, 19, 385-422.

[52] Johnston, J.E. (1991) Fossil Whale: State Fossil of Mississippi. Office of Geology Pamphlet No. 3, Mississippi Dept. of Environmental Quality, Jackson, Mississippi.

[53] Thurmond, J.T. and Jones, D.E. (1981) Fossil Vertebrates of Alabama. The University of Alabama Press, Alabama.

[54] Welton, B.J. and Zinsmeister, W.J. (1980) Eocene neoselachians from the La Meseta formation, Seymour Island, Antarctic Peninsula. Natural History Museum of Los Angeles County, 329, 1-10.

[55] Fostowicz-Frelik (2003) An enigmatic whale tooth from the Upper Eocene of Seymour Island, Antarctica. Polish Polar Research, 24, 13-28.

[56] Aguilera, O.A., Garcia, L. and Cozzuol, M.A. (2008) Giant-toothed white sharks and cetacean trophic interaction from the Pliocene Caribbean Paraguan Formation. Paläontologische Zeitschrift, 82, 204-208. http://dx.doi.org/10.1007/BF02988410

[57] Bianucci, G., Sorce, B., Sorai, T. and Landini, W. (2010) Killing in the Pliocene: Shark attack on a dolphin from Italy. Palaeontology, 53, 457-470. http://dx.doi.org/10.1111/j.1475-4983.2010.00945.x

[58] Bianucci, G., Gatt, M., Catanzariti, R., Sorbi, S., Bonavia, C.G., Curmi, R. and Varola, A. (2011) Systematics, biostratigraphy and evolutionary pattern of the Oligo-Miocene marine mammals from the Maltese Islands. Geobios, 44, 549-585.

http://dx.doi.org/10.1016/j.geobios.2011.02.009

[59] (2012) International Chronostratigraphic chart. www.stratigraphy.org 